\title{
Best Article Award: Hueng
}

\author{
Katherine S. Virgo
}

Published online: 13 March 2014

(C) International Atlantic Economic Society 2014

The Atlantic Economic Journal is proud to announce that the winner of the Best Article Award is C. James Hueng of Western Michigan University. His paper, entitled, "Central Bank Behavior and Statutory Independence," appeared in the June 2012 issue of the $A E J$. A distinguished committee reviewed all eligible papers published in that same year. The committee was chaired by IAES Vice President Asli Demirgüç-Kunt of the World Bank. Members of the committee included the AEJ Board of Editors and IAES Endowment Fund Sponsors. The Managing Editor gratefully acknowledges the participation and diligence of all committee members who participated in the review process. The award emphasizes the intellectual and scholarly approach to economic research which has always been a focal point of the AEJ.

This novel paper integrates the policy reaction function literature with the literature on central bank independence (CBI). The paper compares "what central banks actually do as opposed to what they are legislated to do."

The majority of empirical research on the time inconsistency model has been devoted to testing the relationship between economic performance and the degree of central bank independence measured by various CBI indices, such as the legal CBI. However, the distant link between institutional designs and economic performances complicates testing the relationship between the two due to endogeneity and the missing-variable issues. For this reason, the paper focuses instead on a more direct link between $\mathrm{CBI}$ indices and the central bank behaviors, and analyzes which aspects of the legal CBI are more consistent with central bank behaviors.

Central bank behavior, which reflects the practical CBI, is described by the policy reaction function, in which the monetary policy instrument reacts to information on the state of the economy. If the legal CBI is consistent with the practical CBI, it is expected to be positively associated with the size and the speed of the central banks' reaction to inflation shocks.

The author used macro data from 18 OECD countries during the 1980s to estimate various versions of the Taylor reaction functions. Comparing the estimation results with several published CBI indices, the author found that certain aspects of legislated differences in $\mathrm{CBI}$ generate variations in the anti-inflation behaviors of central banks.

K. S. Virgo $(\bowtie)$

International Atlantic Economic Society, Atlanta, GA 30303, USA

e-mail: iaes@iaes.org 
Specifically, limitations on central bank ability to lend to the government affect central bank reactions to inflation. Conversely, differences in legislated terms of office, appointments, and dismissals of central bank governors have no significant effect on central bank reactions to inflation.

This paper represents a refreshing new direction regarding the evaluation of central bank independence. Even with limited data availability, the author was able to provide robust empirical evidence and thought provoking results. Further research is needed to expand on the work begun by this year's awardee. 